\title{
SÜRDÜRÜLEBILIRLIK PERFORMANS
}

GÖSTERGELERINE ILIŞKIN

AÇIKLAMALARIN FINANSAL

PERFORMANS ÜZERINE ETKISI: BIST'TE

BIR UYGULAMA*

Murat DÜZER ${ }^{a}$

Saime ÖNCE ${ }^{b}$

Ampirik Araştırma

(Empirical Research)

öz

Bu çalışmanın temel amacı; açıklanan sürdürülebilirlik bilgi düzeyinin şirketlerin finansal performansı üzerindeki etkisini incelemektir. Bu amaçla çalışmaya; GRI raporlama ilkelerine göre rapor hazırlayan ve BIST'te işlem gören halka açık 30 şirketin 2008 yılından 2014 yılına kadar olan dönemleri dahil edilmiştir. Sürdürülebilirlik raporlarında açıklanan sürdürülebilirlik bilgi düzeyi; ekonomik, çevresel ve sosyal performans olarak incelenmiştir. Finansal performans ise; aktif karlılığı, özkaynak karlılığı, PD/DD oranı ve F/K oranı gibi finansal oranlar ile ölçülmüştür. Çalışmada panel veri analizi yöntemi uygulanmış ve ayrıca sektör kontrol değişkeni olarak eklenmiştir. Araştırmanın sonucunda; çevresel performansa ilişkin açıklanan bilgi düzeyinin aktif karlılığı ve özkaynak karlılığı, sosyal performansa ilişkin açıklanan bilgi düzeyinin de aktif karlılığı üzerinde pozitif etkiye sahip olduğu tespit edilmiştir.

Anahtar Sözcükler: Sürdürülebilirlik Raporlaması, GRI, Finansal Performans, Panel Veri Analizi

JEL Kodları: Q010, M41, G20, C33

* Makalenin gönderim tarihi: 11.10.2017; Kabul tarihi: 15.10 .2017 ve iThenticate benzerlik oranı \%18

a Bilecik Şeyh Edebali Üniversitesi, Gölpazarı Meslek Yüksek Okulu, Öğretim Görevlisi, E-posta: murat.duzer@bilecik.edu.tr, ORCID: http://orcid.org/0000-0003-4514-0798 (Sorumlu yazar; Correspondent author)

b Anadolu Üniversitesi, Iktisadi ve Idari Bilimler Fakültesi Işletme Bölümü, Öğretim Üyesi, E-posta: sonce@ anadolu.edu.tr, ORCID: http://orcid.org/0000-0001-9828-1872 


\section{EFFECT OF DISCLOSURES ON SUSTAINABILITY PERFORMANCE INDICA- TORS ON FINANCIAL PERFORMANCE: AN APPLICATION IN BIST}

\section{ABSTRACT}

The main purpose of this research is to examine the impact of disclosed sustainability information level on the financial performance of companies. For this purpose the period from 2008 to 2014 of 30 publicly traded companies that prepare reports according to $\mathrm{GRI}$ reporting principles and are traded on the BIST are included. The level of sustainability information disclosed in the sustainability reports has been investigated as economic, environmental and social performance. Financial performance is measured by financial ratios such as asset profitability, return on equity, MV/BV ratio and $\mathrm{P} / \mathrm{E}$ ratio. Panel data analysis method was applied in the research and the sector has been added as a control variable. As a result of this research, the level of information disclosed for environmental performance has positive effect on the return on assets and the return on equity, and the level of information disclosed on social performance has positive effect on the return on assets.

Keywords: Sustainability Reporting, GRI, Financial Performance, Panel Data Analysis

JEL Codes: Q010, M41, G20, C33

\section{GiRiş ${ }^{1}$}

Sürdürülebilirlik raporlaması; son yıllarda üzerinde titizlikle durulan, şirketler tarafindan önem verilen, birçok araştırmaya ilham kaynağı olmuş konuların başında gelmektedir. Sürdürülebilirlik raporlamasının günümüzdeki önemini kazanmasında en önemli noktalardan birisi sürdürülebilir kalkınma kavramıdır. 1987 yılında Brutland Raporunda sürdürülebilir kalkınma; "Gelecek nesillerin kendi ihtiyaçlarını karşılama yeteneklerini tehlikeye sokmaksızın bugünkü nesillerin ihtiyaçlarını karşılayan kalkınma" şeklinde tanımlanmıştır (Brutland, 1987). Dolayısıyla sürdürülebilir kalkınmanın gerçekleşebilmesi için hükümetlere, işletmelere ve daha birçok kesime önemli sorumluluklar düşmektedir. Bu taraflardan ekonominin temel birimi olan işletmelerin üstlendiği bu sorumlulukları hangi ölçüde yerine getirdiğine ilişkin bilgiye, ilgili bütün paydaşların duyduğu ihtiyaç; işletme faaliyetlerine ve bu faaliyetlerin sonuçlarına ilişkin finansal bilgi ile beraber sosyal ve çevresel bilgilerin de raporlanması gereğini doğurmuştur (Önce, Onay ve Yeşilçelebi, 2015, s. 231). Buna bağlı olarak sürdürülebilir kalkın-

1 Bu çalışma, yazarlardan Murat Düzer'in Anadolu Üniversitesi Sosyal Bilimler Enstitüsü işletme ABD'de Prof. Dr. Saime Önce danışmanlığında yürütülen "Sürdürülebilirlik Performans Göstergelerine iliş̧kin Açıklamaların Finansal Performans Üzerine Etkisi" adlı doktora tezinden yararlanılarak hazırlanmıştır. 
ma hedefinin gerçekleşebilmesinde önemli bir yere sahip olan işletmeler; hesap verebilirlik anlayışı çerçevesinde sürdürülebilirlik raporlarında faaliyetlerinin ekonomik, çevresel ve sosyal etki ve sonuçları hakkında bilgi vermektedirler.

Sürdürülebilirlik raporlaması; iç ve dış tüm paydaş gruplarını önemseyen, kurumsal performansın sürekliliğine ve ekonomik, sosyal ve çevresel açılardan değerlendirilmesine katkı sağlayan önemli bir iletişim aracı olarak düşünülebilir. Ayrıca sürdürülebilirlik raporları paydaşlara; işletme faaliyetlerini ve performansını ekonomik, sosyal ve çevresel açıdan değerlendirme imkanı vererek, paydaşların aynı sektörde faaliyet gösteren diğer işletmelerle kıyaslama yapabilmesini sağlayacaktır (BiST, 2014, s. 5). Bu kıyaslamanın daha anlamlı hale gelmesi açısından işletmelere, sürdürülebilirlik raporu düzenleyebilmede rehber olan dünya genelinde kabul edilen sürdürülebilirlik raporlama çerçeveleri bulunmaktadır. Bu raporlama çerçeveleri; sürdürülebilirlik raporlarının açık, anlaşılır ve şeffaf olmasını sağlamanın yanında paydaşların değişen ve gelişen taleplerine uyum sağlayacak şekilde değerlendirilmekte ve yenilenmektedir (Onay, 2015, s. 111).

Dünya genelinde kabul gören en önemli sürdürülebilirlik raporlama çerçevelerinden birisi de GRI(Küresel Raporlama Girişimi) raporlama çerçeveleridir. GRI; işletmelerin, hükümetlerin ve diğer kurumların iklim değişikliği, insan hakları ve yolsuzluk gibi kritik sürdürülebilirlik konuları üzerine işletmenin etkisini anlaması ve anlatmasına yardımcı olan uluslar arası bağımsız bir kuruluştur. GRI, sürdürülebilirlik raporlamasına 1990'lı yılların sonundan itibaren öncülük etmiştir. Bunun temelini GRI sürdürülebilirlik raporlaması standartları oluşturmaktadır (GRI, 2016). Mevcut en eksiksiz kılavuzlardan biri olması, çoklu paydaş katılımını içermesi ve dünya çapında tanınması GRI raporlama çerçevesinin önemli avantajları arasında yer almaktadır (Lozano ve Huisingh, 2011, s. 101).

İşletmelerin içinde bulundukları çevreye ve topluma karşı hassasiyetlerini göstermesi adına sürdürülebilirlik konusuna verdikleri önem, son yıllarda artmakla birlikte bazı ekonomistler(özellikle Friedman) ise; işletmelerin, kurumsal karlılıklarını artırmadıkça sürdürülebilirlik raporuyla ilgilenmeyeceğini ve sürdürülebilirliğin şirket hissedarları için izinsiz bir vergi olduğu görüşünü savunmuştur (Nyit Chiong, 2010 ve Welter, 2011). Buna bağlı olarak zaman içerisinde şirketlerin sürdürülebilirlik bilincinin artmasıyla beraber bunun finansal performans üzerine etkisinin nasıl olduğu sorusu gündeme gelmiştir. Bu noktadan hareketle, bu çalışmanın amacı; Türkiye'de sürdürülebilirlik raporu yayınlayan şirketlerin raporlarında açıkladıkları bilgi düzeyinin finansal performans üzerine etkisinin incelenmesi olarak belirlenmiştir. Yukarıda sayılan avantajlarından dolayı bu çalışmada GRI raporlama çerçevesini kullanarak sürdürülebilirlik raporu hazırlayan 
şirketler incelenmiştir. Çalışmaya; ülkemizde 2008-2014 yılları arasında GRI raporlama çerçevelerini kullanarak sürdürülebilirlik raporu hazırlayan ve hisseleri Borsa İstanbul(BiST)'da işlem gören şirketler dahil edilmiştir.

\section{LITERATÜR}

Bir işletmenin sürdürülebilirlik performansı ve finansal performansı arasındaki ilişkiye yönelik yapılacak araştırma, sürdürülebilirlik konusu içerisinde önemli bir yere sahiptir. Sürdürülebilirlik performansı ve onun finansal sonuçları arasında bulunabilecek pozitif veya negatif ilişki, şirketin politikalarını ve yatırım stratejilerini etkileyebilir (Yılmaz, 2011, s. 73).

Literatür incelendiğinde; sürdürülebilirlik performansı(bazı çalışmalarda sosyal performans, bazı çalışmalarda ise kurumsal sosyal sorumluluk olarak geçmektedir) ile finansal performans arasındaki ilişkiyi araştıran çalışmalarda farklı sonuçlara ulaşıldığı görülmektedir. Sürdürülebilirlik performansı ile finansal performans arasında pozitif ve negatif ilişki bulan çalışmalar olduğu gibi, anlamlı ilişki bulamayan çalışmalar da yer almaktadır. Bu bağlamda öncelikle sürdürülebilirlik performansı ve finansal performans arasındaki ilişkilere yönelik teorik çerçeve ele alınacak ve sonrasında bu teorik çerçeveyi destekleyen ampirik çalışmalar hakkında bilgi verilecektir.

Pozitif ilişki: Son yıllarda yapılan teorik analizler, genel olarak sürdürülebilirlik performansı ile finansal performans arasında pozitif ilişki olduğunu desteklemektedir (Welter, 2011, s. 68).

Sürdürülebilirlik performansı ile finansal performans arasında pozitif ilişki olduğunu savunan görüşlerin ortak paydasını ise paydaş teorisi oluşturmaktadır. Paydaş teorisi, kurumların sadece hissedarlarına karşı değil çeşitli paydaş gruplarına karşı sorumluluğunun olduğunu vurgulamaktadır (Bäckström ve Karlsson, 2015, s. 6). Farklı paydaş gruplarının işletmeden farklı istek ve beklentileri bulunmaktadır ve paydaş teorisi de işletmenin, her bir paydaş grubunun beklentilerinin karşılanması yönünde çaba göstermesinin önemine dikkat çekmektedir.

Paydaş teorisine göre işletmelerin sadece hissedarlarının belli isteklerini değil aynı zamanda çok geniş aralıkta yer alan diğer paydaşlarının kurumsal sürdürülebilirlik performansına ilişkin taleplerini de düşünmeleri gerekmektedir. Zayıf sürdürülebilirlik performansı; diğer paydaşların taleplerinin yerine getirilip getirilemeyeceği konusunda şüphe duymalarına sebep olacak şekilde görüşlerini etkileyebilecektir. Bununla birlikte ortaya konacak iyi bir sürdürülebilirlik performansı ise işletmenin paydaşlarıyla olan ilişkilerini geliştirmesini ve gelecekte sağlayacağı başarıyı güvence altna almasını sağlar (Lee, Faff ve Langfield-Smith, 2009, s. 26). İyi paydaş 
ilişkileri de, işletmenin sadece daha uzun vadede rekabet avantajlarını sürdürmesi için üstün finansal performansa sahip olmasına yardımcı olmakla kalmaz ayrıca dezavantajlı durumlardan daha çabuk kurtulması için kötü performans gösteren işletmelere de yardımcı olur (Choi ve Wang, 2009, s. 895).

Paydaş teorisi temelinde Cornell ve Shapiro $(1987$, s.13) tarafindan ortaya konan sosyal etki hipotezi; daha örtük paydaş ihtiyaçlarının karşılanmasının önemini vurgular. Diğer bir ifadeyle paydaşların daha az açık olan taleplerini karşılamada ortaya çıkacak başarısızık; işletmenin kurumsal itibarını potansiyel olarak etkileyebilecek piyasa şoklarıyla(ürün geri çağırma ve dava açma gibi) sonuçlanabilir. Bu durum da finansal performansın negatif etkilenmesiyle sonuçlanabilir. Bununla birlikte sürdürülebilirlik faaliyetlerinin maliyetleri, potansiyel faydalarıyla karşılaştrııdığında minimum düzeydedir (Salzman ve diğ. 2005, s. 29). Sonuç olarak, işletmenin hissedarlarının dışında kalan paydaş grubunun ihtiyaçlarının başarıyla karşılanması, finansal performansa olumlu yönde etki edecektir.

Yapılan açıklamalar ışığında sürdürülebilirlik performansı ile finansal performans arasında pozitif ilişkinin varlığına yönelik teorik çerçeve; sosyal etki hipotezi, iyi yönetim teorisi ve daha da önemlisi paydaş teorisi ile desteklenmektedir. Bununla birlikte sürdürülebilirlik ve finansal performans arasında pozitif ilişki bulan ampirik çalışmalar da bulunmaktadır. Moskowitz (1972) iyi bir sosyal sorumluluğa sahip ve sosyal sorumluluk aktivitelerine önemli katkılar sağlayan 14 şirket üzerinde gerçekleştirdiği araştırmasında; sosyal harcamalara en fazla bütçe ayıran 14 şirketin hisse fiyatı performanslarını incelemiş ve bu şirketlerin performansının genel endeks performansından yüksek olduğu sonucuna ulaşmıştr. Preston ve Q'Bannon (1997) kurumsal sosyal performans göstergeleri ile finansal performans arasındaki ilişkiyi 1982-1992 döneminde 67 büyük Amerikan firması örneklemini kullanarak araştırmışlardır. Çalışma sonuçları; paydaş teorisiyle tutarlı bir şekilde finansal performans ve sosyal performans arasında pozitif bir ilişki olduğunu göstermektedir. Waddock ve Graves (1997) Kurumsal sosyal performans ve finansal performans arasındaki ilişkiyi inceledikleri çalışmalarında kurumsal sosyal performansın finansal performansa bağıı olduğu sonucu çıkmış ve ilişkinin de pozitif olduğu saptanmıştr. Peters ve Mullen (2007) kurumsal sosyal sorumluluğun finansal performans üzerine kümülatif etkisini incelemişlerdir. Çoklu regresyon yönteminin uygulandığı analiz sonuçlarına göre, kurumsal sosyal sorumluluğun finansal performans üzerindeki etkisinin, zaman içerisinde pozitif bir şekilde arttğı gözlenmiştir. Belu (2009) sürdürülebilirlik uygulamaları ile finansal sonuçlar arasındaki ilişkiyi incelediği çalışmasında bağımsız değişken olarak aktif karııı̆̆ı, özkaynak karlılığı ve yıllık hisse getirisini almıştır. Veri zarf- 
lama analiz tekniğinin kullanıldığı çalışmanın sonuçlarına göre sürdürülebilirliğe önem veren şirketlerin finansal performanslarının daha iyi olduğu bulunmuştur. Ameer ve Othman (2012) sürdürülebilirlik uygulamaları ile finansal performans arasındaki ilişkiyi araştırdıkları çalışmalarında gelişmiş ve gelişen ülkelerden arasından seçtikleri üst düzeyde 100 sürdürülebilir şirketi incelemişlerdir. Analiz sonuçlarına göre; sürdürülebilirlik uygulamalarına önem veren şirketlerin aktif karlılığı, vergi öncesi kar ve nakit akışı göstergelerine göre daha yüksek düzeyde finansal performans sergiledikleri ortaya çıkmıştır. Arsoy ve diğerleri (2012) kurumsal sosyal performans ile muhasebe temelli ölçüleri dikkate alan finansal performans arasındaki ilişkiyi inceledikleri çalışmalarına iMKB kurumsal yönetim endeksinde yer alan 28 şirketi dahil etmişlerdir. Yapılan analiz neticesinde muhasebe temelli finansal göstergeler ile kurumsal sosyal göstergeler arasında pozitif korelasyon saptanmıştir.

Negatif ilişki: Sürdürülebilirlik performansı ile finansal performans arasında negatif ilişki olduğunu savunan görüşün temelinde Friedman'ın argümanı yer almaktadır. Friedman (1970), işletmelerin sadece tek bir sosyal sorumluluğunun olduğunu ve onun da karı artrabilecek faaliyetlerle ilgilenmek ve kaynakları o yönde kullanmak olduğunu ifade etmiştir. Bu görüşe göre sürdürülebilirlik faaliyetleriyle ilgilenen işletmeler daha fazla maliyete katlanmak zorunda kalacak ve bu da finansal performansı düşürecektir. Ayrıca kurumların geleneksel amaçları hissedar değerini maksimum yapmak olduğu için, çalışanları, müşterileri ve hissedarları açısından fayda sağlamayacak yatııımlar yapan herhangi bir yöneticinin kurum kaynaklarını suistimal ettiği yönünde inanç oluşacaktır. Friedman, doğrudan kar elde etmeyi amaçlamayan herhangi bir faaliyetin hissedar değeri üzerinde bir vergi etkisi göstereceğini ve bunun da finansal performansı negatif etkileyeceğini ifade etmiştir (Friedman, 1970). Bununla birlikte Preston ve Q'Bannon (1997) yönetimsel firsatlar hipotezinde; finansal durumun güçlü olması durumunda yöneticilerin bu gücü korumak ve kısa vadeli karlılığı artırmak adına sosyal sorumluluk harcamalarını azaltacağını öne sürmüşlerdir. Bu hipotez de aslında sürdürülebilirlik performansı ile finansal performans arasındaki ilişkinin yönü açısından Friedman'ın görüşüyle örtüşmektedir. Ancak; yönetimsel firsatlar hipotezinde ilişkinin belirleyicisi finansal performans iken, Friedman'ın görüşünde ilişkinin belirleyicisi sosyal performanstir.

Çalışmalarında sürdürülebilirlik ve finansal performans arasında negatif ilişki bulan araştırmacılardan biri olan Vance (1975) çalışmasında; Moskowitz'in 1972 yılında yaptığı araştırmada yer alan firmaların 19721975 yılları arasındaki hisse performanslarını incelemiştir. Moskowitz'in bulduğu sonucun aksine sosyal sorumluluğa daha fazla önem veren fir- 
maların belirtilen dönemde sosyal sorumluluğu daha düşük olan firmalara göre daha kötü bir performans gösterdiği sonucunu ortaya koymuştur. Lopez, Garcia ve Rodrigez (2007) ise; benzer boyut ve sermaye yapısına sahip 110 şirketi inceledikleri çalışmalarında bu şirketlerin 55'ini Dow Jones Sürdürülebilirlik Endeksine dahil olan şirketlerden, 55'ini ise Dow Jones Global Endeksine dahil olan şirketlerden seçmişlerdir. Regresyon analizini kullandıkları çalışmanın sonuçlarına göre; kısa dönemde kurumsal sosyal sorumluluk uygulamalarının performans üzerine etkisi negatif olarak bulunmakla beraber zaman geçtikçe bu negatif etkinin azaldığı gözlenmiştir.

Nötr ilişki (ilişki yok): Sürdürülebilirlik performansı ile finansal performans arasında nötr veya belirlenemeyen bir ilişki olduğunu savunan görüş; uzun dönemli farklılıkların varlığını engelleyen arz ve talebe(piyasa işleyişine), değişkenler arasındaki etkileşime ve etkilenen değişkenlerin sayısına odaklanmıştır (Welter, 2011, s. 67). Ullmann (1985, s. 551), sosyal performans ile finansal performans arasındaki ilişkide araya giren çok sayıda değişken olduğunu ve bu sebeple sosyal performans ile finansal performans arasında doğrusal ilişki kurmanın bir nedeni olmadığını ifade etmiştir. Mc Williams ve Siegel (2001, s. 125 ) ise; ortaya koydukları arz ve talep çerçevesi ile kurumsal sosyal sorumluluk ile finansal performans arasındaki ilişkinin nötr olduğunu ifade etmişlerdir. Bu görüşe göre; işletmelerden sosyal sorumlu davranmasını talep eden paydaşlar bulunmaktadır. İşletme de bu paydaşların talebini yerine getirmek için sosyal sorumluluğa uygun davranış ortaya koyar. İşletme bunu gerçekleştirebilmek için harcamalarını artiracak ve daha fazla maliyete katlanacaktır. Yani işletme sosyal sorumlu davranması sonucu daha fazla gelir elde edebileceği gibi de daha fazla maliyete de katlanması gerekecektir. Kurumsal sosyal sorumluluk özellikleri ortaya koymayan bir işletme ise daha az maliyete katlanırken daha az gelir elde edecektir. Diğer bir ifadeyle kurumsal sosyal sorumluluk özellikleri gösteren işletme ile göstermeyen işletme farklı şekillerde karı maksimum düzeye getirmek için hareket edecektir. Kurumsal sosyal sorumluluk özellikleri, karı artırmak için kullanılabilecek herhangi bir özellik gibidir. İşletmeler karlarını maksimum yapabilmek için bu özelliklerden herhangi birini seçebilirler. Dolayısıyla kurumsal sosyal sorumluluk faaliyetleri ile finansal performans arasında genel olarak nötr bir ilişki bulunmaktadır.

Sürdürülebilirlik ve finansal performans arasında nötr ilişki(ilişki yok) sonucu bulan araştırmacılardan Alexander ve Buchholz (1978) kurumsal sosyal sorumluluk ve finansal performans arasındaki ilişkiyi inceledikleri çalışmalarında; Moskowitz ve Vance'in araştırmalarında riske uyarlanmış piyasa performansını dikkate almadıklarını belirterek bu konu üzerine eğilmişlerdir. Vance'in çalışmasındaki sosyal sorumluluk sıralamaları bu 
çalışmada esas alınmış olup inceleme 1970-1974 dönemi ve 1971-1973 alt dönemi için gerçekleştirilmiştir. Belirtilen zaman periyotlarında hisselerin risk uyumlu getirileri hesaplanmış ve sosyal sorumluluk dereceleri ile karşılaştrıldığında sosyal sorumluluğun hisse performansı üzerinde önemli bir etkisinin bulunmadığı sonucuna ulaşıımıştır. Aupperle ve diğerleri (1985); kurumsal sosyal sorumluluk ve karlılık arasındaki ilişkiyi inceledikleri çalışmalarında kurumsal sosyal sorumluluğu tanımlamada 4 boyutu olan bir anket yöntemi kullanmışlardır. Bu dört boyut; ekonomik, yasal, etik ve isteğe bağlı olan hayırseverliktir. Bu alanlarla ilgili olarak yanıtlayıcıların (CEO'lar) zorunlu olarak seçecekleri ifadeler yer almıştır. Finansal performans göstergesi olarak da aktif karlıığı dikkate alınmıştır. Yapılan analiz neticesinde kurumsal sosyal sorumluluk ve karlılık arasında istatistiki olarak anlamlı bir ilişkiye rastlanmamıştır. Nyit Chiong (2010) da dünyanın farklı ülkelerinde GRI'ya göre sürdürülebilirlik raporu hazırlayan firmaların ekonomik, sosyal, çevresel ve sürdürülebilirlik performans bilgisi ile finansal performansları arasındaki ilişkiyi araştırmıştı. Çalışmanın sonuçlarına göre ekonomik, çevresel ve sosyal performans ile gelir arţ̧ıı ve özkaynak karlıı̆̆ arasında anlamlı bir ilişki bulunamamıştr. Özçelik, Öztürk ve Gürsakal (2014) BiST 100 endeksinde yer alan şirketlerin 2010-2012 yıllarındaki verilerini esas alarak kurumsal sosyal sorumluluk ile finansal performans arasındaki ilişkiyi incelemişlerdir. Çalışmalarında; şirket büyüklüğü değişkeninin dışında bağımsız değişken olarak belirledikleri finansal göstergeler, kaldıraç oranı ve sahiplik yapısı ile kurumsal sosyal sorumluluk arasında anlamlı bir ilişkiye rastlamamışlardır.

Yapılan çalışmaların çoğunda sürdürülebilirlik performansı ile finansal performans arasında pozitif ilişkinin bulunması nedeniyle ve paydaş teorisiyle beraber sosyal etki hipotezi ve iyi yönetim teorisi temel alınarak hipotezler oluşturulmuştur. Ayrıca şirketlerin sürdürülebilirlik performans göstergelerine(ekonomik, çevresel ve sosyal) yönelik açıkladıkları bilgi düzeyinin şirketin finansal performansı üzerine etkisinin; sektör değişkeni dikkate alındıktan sonra farklılık gösterip göstermediği incelenmek istenmiştir. Bu doğrultuda çalışmanın hipotezleri aşağıdaki gibi oluşturulmuştur:

H1: Şirketlerin sürdürülebilirlik performans göstergelerine(ekonomik, çevresel ve sosyal) yönelik açıkladıkları bilgi düzeyinin şirketin aktif karlılı̆ı üzerinde pozitif etkisi vardır.

H1a: Sektörler dikkate alındıktan sonra; şirketlerin sürdürülebilirlik performans göstergelerine(ekonomik, çevresel ve sosyal) yönelik açıkladıkları bilgi düzeyinin şirketin aktif karlıığı üzerinde pozitif etkisi vardır.

H2: Şirketlerin sürdürülebilirlik performans göstergelerine(ekonomik, çev- 
resel ve sosyal) yönelik açıkladıkları bilgi düzeyinin şirketin özkaynak karlılığı üzerinde pozitif etkisi vardır.

H2a: Sektörler dikkate alındıktan sonra; şirketlerin sürdürülebilirlik performans göstergelerine(ekonomik, çevresel ve sosyal) yönelik açıkladıkları bilgi düzeyinin şirketin özkaynak karlılığı üzerinde pozitif etkisi vardır.

H3: Şirketlerin sürdürülebilirlik performans göstergelerine(ekonomik, çevresel ve sosyal) yönelik açıkladıkları bilgi düzeyinin şirketin PD/DD oranı üzerinde pozitif etkisi vardır.

H3a: Sektörler dikkate alındıktan sonra; şirketlerin sürdürülebilirlik performans göstergelerine(ekonomik, çevresel ve sosyal) yönelik açıkladıkları bilgi düzeyinin şirketin PD/DD oranı üzerinde pozitif etkisi vardır.

H4: Şirketlerin sürdürülebilirlik performans göstergelerine(ekonomik, çevresel ve sosyal) yönelik açıkladıkları bilgi düzeyinin şirketin F/K oranı üzerinde pozitif etkisi vardır.

H4a: Sektörler dikkate alındıktan sonra; şirketlerin sürdürülebilirlik performans göstergelerine(ekonomik, çevresel ve sosyal) yönelik açıkladıkları bilgi düzeyinin şirketin $\mathrm{F} / \mathrm{K}$ oranı üzerinde pozitif etkisi vardır.

\section{VERI VE YÖNTEM}

\subsection{Veri}

Çalışmaya; 2008-2014 yılları arasında GRI raporlama çerçevelerini kullanarak sürdürülebilirlik raporu hazırlayan ve hisse senetleri BIST'te işlem gören toplam 30 şirket dahil edilmiştir.

Sürdürülebilirlik performans göstergelerine ilişkin açıklamaların finansal performansa etkisinin incelenmesi amacıyla yapılacak bu çalışmada bağımlı ve bağımsız değişken ile kontrol değişkeni Tablo-1'deki gibi belirlenmiştir.

Tablo-1: Çalışmanın Değişkenleri

\begin{tabular}{|c|c|c|c|}
\hline \multicolumn{2}{|c|}{ Bağımlı Değişkenler } & \multirow{2}{*}{$\begin{array}{c}\text { Bağımsız } \\
\text { Değişkenler }\end{array}$} & Kontrol Değişkeni \\
\cline { 1 - 2 } Muhasebe Temelli & Piyasa Temelli & EKO & Sektör \\
\hline Aktif Karlılığı (AK) & PD/DD oranı & ÇEV & \\
\hline $\begin{array}{c}\text { Özkaynak Karlıı̆ı̆ı } \\
\text { (ÖZKK) }\end{array}$ & F/K oranı & SOS & \\
\hline & & \multicolumn{2}{|c|}{} \\
\hline
\end{tabular}




\subsubsection{Bağımlı Değişken}

Çalışmanın bağımlı değişkenini finansal performans ölçüleri oluşturmaktadır. Literatürde yer alan çalışmalarda finansal performans ölçüleri olarak; muhasebe temelli ve piyasa temelli ölçülerin ağırıklı olarak kullanıldığı sonucuna ulaşılabilir. Muhasebe temelli ölçüler, objektif olma yönlerinin ağır basması nedeniyle tercih edilirken; piyasa temelli ölçüler ise piyasa katılımcılarının şirket hisse senetleri üzerindeki özellikle geleceğe yönelik beklentilerini yansıtması sebebiyle tercih edilmektedir. Bu sebeple çalışmada finansal performans göstergesi olarak muhasebe temelli ölçülerden aktif karlılığı ve öz kaynak karlılığı ile piyasa temelli ölçülerden PD/DD oranı ve $\mathrm{F} / \mathrm{K}$ oranı kullanılacaktır. Muhasebe temelli ve piyasa temelli ölçülerin birlikte kullanılması suretiyle; tek bir grupta yer alan finansal performans ölçülerini kullanmanın neden olacağı zayıflıkların önüne geçilerek bütüncül bir değerlendirme yapma imkanı olacaktır.

Çalışmada modele bağımlı değişken olarak dahil edilecek finansal performans ölçüleri; sürdürülebilirlik raporunun ait olduğu yılı izleyen döneme ait verilerden oluşacaktır. Ayrıca finansal veriler; Kamuoyu Aydınlatma Platformu ve İş Yatırım internet sitesinden ulaşılan mali tablolardan ve FINNET internet sitesinden elde edilmiştir.

\subsubsection{Bağımsız Değişken}

Çalışmanın bağımsız değişkeni, şirketlerin sürdürülebilirlik raporlarında açıkladıkları bilgi düzeyine dayanarak hesaplanan şirket sürdürülebilirlik skorlarıdır. Şirket sürdürülebilirlik skorları; ekonomik skor(EKO), çevresel skor(ÇEV) ve sosyal skor(SOS) şeklinde ifade edilecektir.

Çalışmada; şirketlerin sürdürülebilirlik skorlarını belirlemek için, GRI raporlama çerçevelerinden G3.1 raporlama çerçevesi esas alınarak hazırlanan kontrol listesi kullanılmıştır. Bu kontrol listesinde G3.1 raporlama çerçevesine göre; 9 adet ekonomik performans göstergesi, 30 adet çevresel performans göstergesi ve 45 adet sosyal performans göstergesi olmak üzere toplam 84 adet sürdürülebilirlik performans göstergesi yer almaktadır.

Şirketlerin kontrol listesinde yer alan sürdürülebilirlik performans göstergelerine ilişkin sürdürülebilirlik raporlarında açıkladıkları bilgi düzeyi; Morhardt, Baird ve Freeman (2002)'ın geliştirmiş oldukları skorlama modeline benzer bir model kullanılarak ölçülecek ve her bir şirketin sürdürülebilirlik skoru hesaplanacaktır. Bu skorlama modelinde temel strateji şöyledir:

Kontrol listesinde yer alan göstergelere ilişkin ;

- Bir açıklama yok ise 0;

- Genel olarak ve kısaca bilgi verilmişse 1; 
- Daha detaylı sadece niteliksel, fakat sayısal olmayan bilgi verilmişse 2;

- Diğer şirketlerle karşılaştırılabilmeye imkan verecek ölçüde niteliksel ve sayısal (mutlak veya nispi) ölçütlere yer verildiyse 3 skoru verilecektir.

Her bir sürdürülebilirlik performans göstergesine verilen skorlar toplanarak şirketlerin ekonomik, çevresel, sosyal ve toplam sürdürülebilirlik skoruna ulaşılacaktır.

Şirketlerin sürdürülebilirlik göstergelerine ilişkin açıkladıkları bilgi düzeyi tespit edilirken, şirketlerin GRI raporlama çerçevelerine göre yayınlamış oldukları sürdürülebilirlik raporlarına, şirketlerin internet sitesi ile kurumsalsurdurulebilirlik.com internet sitesinden ulaşılmıştır.

\subsubsection{Kontrol Değişkeni}

Çalışmada kontrol değişkeni olarak sektör alınacaktır. Sürdürülebilirlik performansı ile finansal performans arasındaki ilişki incelenirken şirketin faaliyet gösterdiği sektörün de dikkate alınması gerektiği araştırmacılar tarafindan vurgulanmıştır. Bu bağlamda Ullman (1985, s. 549); şirketlerin sosyal performansı ile finansal performansı arasındaki ilişkiyi açıklamada sosyal performans açıklamalarının sektör, şirket boyutu gibi değişkenlere bağlı olduğunu ifade etmiştir. Waddock ve Graves (1997, s. 309) ise; kurumsal sosyal performans açısından sektörel farklılıkların dikkate alınmamasının; kurumsal sosyal sorumluluğun finansal performans üzerindeki ana etkilerinin anlaşılmasını zorlaştırabileceğini belirtmiştir. Çünkü sektörün özelliklerine bağlı olarak şirketin belli alanlarda önemli problemlerle karşılaşma ya da karşılaşmama durumu bulunmaktadır. Buna göre; şirketlerin faaliyet gösterdiği sektörün; ekonomik, çevresel ve sosyal yani sürdürülebilirlik performansı üzerinde etkili olması beklenmektedir.

Çalışma örnekleminde yer alan şirketlerin sektörlerinin belirlenmesinde BIST tarafindan yapılan sektör sınıflaması kullanılmıştır. Buna göre çalışma örneklemindeki şirketler; mali sektör, imalat sanayi sektörü, enerji(elektrik, gaz, su) sektörü, toptan ve perakende ticaret sektörü, ulaştırma haberleşme ve depolama sektörü olmak üzere beş sektöre ayrılmıştır.

\subsection{Araştırmanın Yöntemi}

Sürdürülebilirlik performans göstergelerine ilişkin açıklanan bilgi düzeyinin finansal performansa etkisi panel veri regresyon analizi ile incelenmiştir. Panel verilerin kullanılması suretiyle değişkenler arasında ilişkilerin tahmin edilmesi yöntemine panel veri analizi denir (Erdemi, 2015, 79). Panel veri; hem kesit hem de zaman serisi verilerini içeren bir yapıya sahiptir. Panel verisinde aile, işletme gibi birimlerin zaman içindeki belli özellikleri gözlenir (Gujarati ve Porter, 2014, ss. 22-23; 591). 
Panel veri regresyonu, regresyon denkleminde yer alan değişkenlerde çift alt simge yer alması sebebiyle yatay kesit ya da zaman serisi regresyonundan farklıdır (Baltagi, 2005, s. 11). Panel veri regresyon denklemi aşağıdaki gibi ifade edilebilir:

$Y_{i t}=\beta_{1 i t}+\beta_{2 i t} X_{2 i t}+\ldots .+\beta_{k i t} X_{k i t}+e_{i t} \quad i=1, \ldots . ., N ; \quad t=1, \ldots . ., T$

Bu denklemde $\mathrm{i}$ işletme, ülke gibi birimleri, $\mathrm{t}$ ise zamanı belirtir. Denklemde görüldüğü gibi değişkenlerin, parametrelerin ve hata teriminin i ve $t$ alt simgelerini taşıması denklemin panel veri modeli olduğunu göstermekte$\operatorname{dir}$ (Tatoğlu, 2016, ss. 4-5).

Panel veri regresyon analizi yapılmadan önce; analize dahil edilecek değişkenlerin durağan olup olmadığının incelenmesi gerekmektedir. Durağan olmayan serilerde yapılacak analiz, değişkenler arasında sahte ilişkilere dayalı yanıltıı sonuçlar verebilmektedir. Bu sebeple analiz gerçekleştirilmeden önce panel veri modelini oluşturan serilerin durağanlığı test edilmelidir. Panel veri analizlerinde durağanlığı test etmek için panel birim kök testlerinden yararlanılır (Tatoğlu, 2013, s. 199). Çalışmada; panel birim kök testlerinden dengesiz panel verisi için uygun olan (Tatoğlu, 2013, ss. 213-215); Im, Peseran ve Shin(2003), Fisher ADF(Maddala ve Wu, 1999), Fisher, Philips ve Perron (Choi, 2001) birim kök testleri kullanıımıştr. Çalışmada gerçekleştirilen birim kök testlerine ilişkin sonuçlar Tablo-2'de özet olarak verilmiştir:

Tablo-2: Birim Kök Testi Sonuçları

\begin{tabular}{|c|l|c|l|l|l|l|}
\hline & \multicolumn{2}{|c|}{ Im, Pesaran and Shin } & \multicolumn{2}{c|}{ Fischer ADF } & \multicolumn{2}{c|}{ Fischer Philips Perron } \\
\hline $\begin{array}{c}\text { Değiş- } \\
\text { kenler }\end{array}$ & Düzey & 1.Fark & Düzey & 1.Fark & Düzey & 1.Fark \\
\hline EKO & Durağan değil & Durağan & Durağan değil & Durağan & Durağan değil & Durağan \\
\hline ÇEV & Durağan değil & Durağan & Durağan değil & Durağan & Durağan & \\
\hline SOS & Durağan & & Durağan & & Durağan & \\
\hline AK & Durağan & & Durağan & & Durağan & \\
\hline ÖZKK & Durağan & & Durağan & & Durağan & \\
\hline FK & Durağan & & Durağan & & Durağan & \\
\hline PDDD & Durağan & & Durağan & & Durağan & \\
\hline
\end{tabular}

Tablo 2'den görüleceği üzere EKO ve ÇEV değişkenleri düzeyde durağan değildir, diğer bir ifadeyle birim kök içermektedir. Bu değişkenlerde 1. Farklar alınmak suretiyle test tekrar gerçekleştirilmiş ve seriler durağan hale gelmiştir. SOS, AK, ÖZKK, FK ve PDDD serileri ise düzeyde durağan özellik göstermektedir.

Panel veri modellerinde hata terimi ve katsayılara ilişkin farklı varsayımlara 
göre farklı panel veri modelleri oluşturulabilir. Temel olarak bu modeller; sabit etkiler ve tesadüfi etkiler panel veri modelleridir (Pazarlığlu ve Gürler, 2007, s. 37). Panel veri regresyon analizinin hangi modele göre yapılacağı Hausman tarafindan önerilen test ile gerçekleştirilmektedir (Greene, 2003, s. 301).

Çalışmada gerçekleştirilen Hausman testi sonuçları Tablo-3'te gösterilmiştir.

Tablo-3: Hausman Testi Sonuçları

\begin{tabular}{|l|l|l|c|}
\hline & Test istatistiği & $\begin{array}{l}\text { P(olasılık) } \\
\text { değeri }\end{array}$ & Model Seçimi \\
\hline Model 1(AK) & 7,580505 & 0,0555 & Tesadüfi Etkiler Modeli \\
\hline Model 2(ÖZKK) & 9,456213 & 0,0238 & Sabit Etkiler Modeli \\
\hline Model 3(PD/DD) & 5,409219 & 0,1442 & Tesadüfi Etkiler Modeli \\
\hline Model 4(F/K) & 3,905693 & 0,2718 & Tesadüfi Etkiler Modeli \\
\hline
\end{tabular}

Her bir modele ayrıca sektör kontrol değişkeni dahil edilecektir. Sektörün kontrol değişkeni olarak dahil edildiği modellerde; sabit etkiler modelinde çoklu doğrusal bağlant sorunu yaşanması nedeniyle model tahmin edilememiş ve bu sebeple tesadüfi etkiler modeli kullanılacaktır. Tablodan da görüleceği üzere Hausman Test istatistiğine ait $P$ değeri 0,05 'ten büyük olduğu durumlarda tesadüfi etkiler modeli, $\mathrm{P}$ değeri $0,05^{\prime}$ ten küçük olduğu durumlarda ise sabit etkiler modeli kullanılarak panel veri analizi gerçekleştirilecektir. Buna bağlı olarak çalışmada oluşturulan panel veri modelleri aşağıdaki gibi ifade edilebilir:

$F P_{i t+1}=\beta_{1 i t}+\beta_{2} E O_{i t}+\beta_{3} C_{C E V}+\beta_{4} S_{\text {SOS }}+e_{i t}$

$\mathrm{FP}_{\mathrm{it}+1}=\beta_{1 \mathrm{it}}+\beta_{2} \mathrm{EKO}_{\mathrm{it}}+\beta_{3} \mathrm{CEV}_{\mathrm{it}}+\beta_{4} \mathrm{SOS}_{\mathrm{it}}+\beta_{5} \mathrm{MALi}_{\mathrm{it}}+\beta_{6} \mathrm{iMALAT}_{\mathrm{it}}+\beta_{7} \mathrm{ENERJi}_{\mathrm{it}}$ $+\beta_{8}$ ULASSTIRMA $_{i t}+\mathrm{e}_{i t}$

Denklemlerde; $\mathrm{FP}_{\mathrm{itt}+1}: \mathrm{t}+1$ dönemine ait ilgili finansal performans ölçüsünü, EKO: Ekonomik skoru, ÇEV: Çevresel skoru ve SOS: Sosyal skoru ifade etmektedir. Ayrıca i : Şirketleri, t: Zamanı, $\beta_{1}, \beta_{2} \ldots \beta_{4}$ : Bağımsız değişken katsayılarını, $\beta_{5}, \beta_{6} \ldots \beta_{8}$ : Sektörlere ait katsayılarıve $\mathrm{e}_{\mathrm{it}}$ : Hata terimini göstermektedir.

\section{BULGULAR VE YORUM}

\subsection{Sürdürülebilirlik Performans Göstergelerine ilişkin Açıklanan Bilgi Düzeyinin Aktif Karlılığı Üzerindeki Etkisine Yönelik Bulgular}

Sürdürülebilirlik performans göstergelerine ilişkin (EKO, ÇEV ve SOS) açıklanan bilgi düzeyinin aktif karlılı̆ı üzerine etkisi, Hausman testi sonuçla- 
rına göre tesadüfi etkiler panel veri analizi yöntemiyle analiz edilmiştir. Analiz sonuçları Tablo-4'te gösterilmiştir.

Tablo-4: Sürdürülebilirlik Skorlarının AK Üzerindeki Etkisi

\begin{tabular}{|c|l|r|r|l|}
\hline Bağımlı değişken: AK & & & & \\
\hline Bă̆ımsız değişkenler & Katsayılar & Standart hatalar & t istatistikleri & p(olasılık) \\
\hline C & 0.008093 & 0.018449 & 0.438679 & 0.6620 \\
\hline EKO & 0.001149 & 0.001123 & 1.022421 & 0.3094 \\
\hline ÇEV & 0.000790 & 0.000362 & 2.180598 & $0.0319 * *$ \\
\hline SOS & 0.000757 & 0.000311 & 2.432421 & $0.0170^{* *}$ \\
\hline$R^{2}$ & 0.196945 & $\begin{array}{l}\text { F istatistiği P } \\
\text { değeri }\end{array}$ & 0.000250 & \\
\hline F istatistiği & 7.112095 & $\begin{array}{l}\text { Durbin Watson } \\
\text { ístatistiği }\end{array}$ & 1.937777 & \\
\hline
\end{tabular}

**\%5 önem düzeyinde istatistiki olarak anlamlı

Tablo-4'ten görüleceği üzere modelin anlamlılığını gösteren $\mathrm{F}$ istatistiğinin p değeri $(0,000250)$ 0,05'ten küçüktür. Bu, modelin istatistiki olarak anlamlı olduğunu göstermektedir. $R^{2}$ değeri bağımsız değişkenlerin bağımlı değişkendeki değişmeyi açıklama gücünü göstermektedir. Tablo 4.'te görülen $\mathrm{R}^{2}$ değeri olan 0,196945; bağımlı değişkende meydana gelebilecek yaklaşık \%20'lik değişmenin, bu modelde yer alan bağımsız değişkenlerdeki değişimlerle açıklanabileceğini ortaya koymaktadır.

Regresyon analizinde sağlıklı yorumlar yapılabilmesi için kurulan modelde otokorelasyonun olmaması gerekir. Durbin Watson istatistiği, otokorelasyonun test edilmesinde sık kullanılan bir yöntemdir. Genel olarak Durbin Watson istatistik değeri 0 ile 4 arasında yer almaktadır. Durbin Watson istatistik değerinin 2 civarında olması, modelde otokorelasyon olmadığını göstermektedir (Yıldırtan, 2010, s. 163; Kutlar, 2005, s.157). Durbin Watson istatistik değerinin 2'ye yakın olması $(1,93)$, modelde otokorelasyon sorununun olmadığını göstermektedir.

Bağımsız değişkenlerin bağımlı değişken üzerindeki etkileri incelendiğinde; ÇEV ve SOS'un aktif karlılığı üzerinde istatistiki olarak anlamlı pozitif etkiye sahip olduğu gözükmektedir ( $p$ değerleri sırasıyla: 0,0319 ve 0,017). Diğer bir ifadeyle çevresel ve sosyal performans göstergelerine ilişkin açıklanan bilgi düzeyinde meydana gelebilecek artış, aktif karlılığını olumlu yönde etkileyecektir. Buna karşılık EKO bağımsız değişkeninin aktif karlılığı üzerinde istatistiki olarak anlamlı bir etkiye sahip olmadığı sonucu ortaya çıkmıştır ( $p>0,30949$ ). Bu sonuçlara göre; H1 hipotezi KABUL edilir (Modelin $p$ değeri $0,000792<0,05)$. 
Sektör: Sektörlerin daha önce oluşturulmuş olan panel veri modeline (model 1) kontrol değişkeni olarak dahil edilmesi suretiyle gerçekleştirilen panel veri analizine yönelik sonuçlar Tablo-5'te gösterilmiştir:

Tablo-5: Sektörlerin AK üzerindeki etkilerinin analizi

\begin{tabular}{|c|c|c|c|c|}
\hline \multicolumn{5}{|l|}{ Bağımlı değişken: AK } \\
\hline Bağımsız değişkenler & Katsayılar & Standart hatalar & $\mathrm{t}$ istatistikleri & p(olasılık) \\
\hline C & 0.015966 & 0.016381 & 0.974676 & 0.3326 \\
\hline EKO & 0.001297 & 0.001080 & 1.200816 & 0.2332 \\
\hline ÇEV & 0.000615 & 0.000460 & 1.336454 & 0.1851 \\
\hline sos & 0.000999 & 0.000158 & 6.318126 & 0.0000 \\
\hline MALI & -0.054199 & 0.010391 & -5.216164 & 0.0000 \\
\hline IMALAT & 0.001664 & 0.014389 & 0.115624 & 0.9082 \\
\hline ELEKTRIK, GAZ, SU & -0.105547 & 0.023309 & -4.528248 & 0.0000 \\
\hline $\begin{array}{l}\text { ULAŞTIRMA, } \\
\text { HABERLEŞME, } \\
\text { DEPOLAMA }\end{array}$ & 0.028748 & 0.016179 & 1.776798 & 0.0793 \\
\hline $\mathrm{R}^{2}$ & 0.543573 & $\begin{array}{c}\text { F istatistiği P } \\
\text { değeri }\end{array}$ & 0.000000 & \\
\hline $\mathrm{F}$ istatistiği & 1.412103 & $\begin{array}{l}\text { Durbin Watson } \\
\text { İstatistiği }\end{array}$ & 2.135318 & \\
\hline
\end{tabular}

Tablo-5'ten görüleceği üzere modelin anlamlılığını gösteren $\mathrm{F}$ istatistiğinin p değeri (0.0000) 0,05'ten küçüktür. Bu, modelin istatistiki olarak anlamlı olduğunu göstermektedir. $R^{2}$ değerinin 0,543573 olması ise; bağımlı değişkende meydana gelebilecek \%54'lik değişmenin, bu modelde yer alan bağımsız değişkenlerdeki değişimlerle açıklanabileceğini ortaya koymaktadır. Bu oranın yüksek olması modelin gücünü artırmaktadır. Durbin Watson istatistik değerinin 2'ye yakın olması $(2,13)$ da modelde otokorelasyon sorununun olmadığını göstermektedir.

Modelin istatistiki olarak anlamlı çıkması; sektörler dikkate alındığında sürdürülebilirlik performans göstergelerine ilişkin açıklanan bilgi düzeyinin aktif karlılığı üzerinde etkisinin olduğunu ifade etmektedir. Bununla birlikte ÇEV'in aktif karlılığı üzerindeki etkisini gösteren katsayı sektörler modele dahil edildikten sonra istatistiki olarak anlamsız iken SOS'un etkisi hala istatistiki olarak anlamlıdır. Diğer bir ifadeyle ÇEV'in etkisi sektörler dikkate alındıktan sonra değişmiştir. Dolayısıyla sektörler arasında şirketlerin sürdürülebilirlik performans göstergelerine ilişkin açıklama düzeyleri arasındaki farklılıklar önemli hale gelmektedir. Tablodaki sonuçlardan ayrıca farklı sektörlerde yer alan şirketlerde, SOS'un aktif karlılığı üzerindeki etkisinin değiştiği görülmektedir. Bu sonuçlara göre; H1a hipotezi KABUL edilir (Modelin p değeri 0,0000<0,05). 


\subsection{Sürdürülebilirlik Performans Göstergelerine ilişkin Açıklanan Bilgi Düzeyinin Özkaynak Karlılığı Üzerindeki Etkisine Yönelik Bulgular}

Sürdürülebilirlik performans göstergelerine ilişkin (EKO, ÇEV ve SOS) açıklanan bilgi düzeyinin özkaynak karlılığı üzerine etkisi Hausman testi sonuçlarına göre sabit etkiler panel veri analizi yöntemiyle incelenmiştir. Analiz sonuçları Tablo-6'da yer almaktadır.

Tablo-6: Sürdürülebilirlik Skorlarının ÖZKK Üzerindeki Etkisi

\begin{tabular}{|c|c|c|c|c|}
\hline Bağımlı değişken: ÖZKK & & & & \\
\hline Bağımsız değişkenler & Katsayılar & Standart hatalar & t istatistikleri & p(olasılık) \\
\hline C & 0.261771 & 0.110591 & 2.367 .024 & 0.0210 \\
\hline EKO & 0.012127 & 0.007475 & 1.622 .359 & 0.1097 \\
\hline ÇEV & 0.005530 & 0.003208 & 1.723 .916 & $0.0896^{* * *}$ \\
\hline SOS & -0.002920 & 0.002087 & -1.399 .104 & 0.1667 \\
\hline$R^{2}$ & 0.571930 & F istatistiği P değeri & 0.000074 & \\
\hline F istatistiği & 3.237390 & $\begin{array}{c}\text { Durbin Watson } \\
\text { İstatistiği }\end{array}$ & 2.408185 & \\
\hline
\end{tabular}

***\%10 önem düzeyinde istatistiki olarak anlamlı

Tablo-6'dan görüleceği üzere modelin anlamlılığını gösteren $F$ istatistiğinin $p$ değeri $(0,000074) 0,05$ 'ten küçüktür. $\mathrm{Bu}$, modelin istatistiki olarak anlamlı olduğunu göstermektedir. $\mathrm{R}^{2}$ değerinin 0,57193 olması; bağımlı değişkende meydana gelebilecek \%57'lik değişmenin, bu modelde yer alan bağımsız değişkenlerdeki değişimlerle açıklanabileceğini ortaya koymaktadır. Bu oranın yüksek olması modelin gücünü artırmaktadır. Durbin Watson istatistik değerinin 2'ye yakın olması $(2,40)$ da modelde otokorelasyon sorununun olmadığını göstermektedir.

Bağımsız değişkenlerin bağımlı değişken üzerindeki etkileri incelendiğinde; ÇEV'in özkaynak karlılığı üzerinde \%10 önem düzeyinde istatistiki olarak anlamlı pozitif etkiye sahip olduğu görülmektedir ( $p$ değeri: 0,0896 ). Diğer bir ifadeyle çevresel performans göstergelerine ilişkin açıklanan bilgi düzeyinde meydana gelebilecek artş̧, özkaynak karlılı̆ını olumlu yönde etkileyecektir. Buna karşılık EKO ve SOS bağımsız değişkenlerinin özkaynak karlıığı üzerinde istatistiki olarak anlamlı bir etkiye sahip olmadığı sonucu ortaya çıkmıştır. Bu sonuçlara göre; $\mathbf{H 2}$ hipotezi KABUL edilir (Modelin $p$ değeri $0,000074<0,05)$.

Sektör: Sektörlerin daha önce oluşturulmuş olan panel veri modeline (model 2) kontrol değişkeni olarak dahil edilmesi suretiyle gerçekleştirilen panel veri analizine yönelik sonuçlar Tablo-7'de gösterilmiştir: 
Tablo-7: Sektörlerin ÖZKK Üzerindeki Etkilerinin Analizi

\begin{tabular}{|c|c|c|c|c|}
\hline \multicolumn{5}{|l|}{ Bağımlı değişken: ÖZKK } \\
\hline Bağımsız değişkenler & Katsayılar & $\begin{array}{l}\text { Standart } \\
\text { hatalar }\end{array}$ & $\mathrm{t}$ istatistikleri & $\mathrm{p}$ (olasılık) \\
\hline C & 0.159106 & 0.042243 & 3.766453 & 0.0003 \\
\hline EKO & 0.008141 & 0.005221 & 1.559279 & 0.1228 \\
\hline ÇEV & 0.004785 & 0.003027 & 1.581061 & 0.1177 \\
\hline sos & 0.000457 & 0.000572 & 0.797977 & 0.4272 \\
\hline MALI & -0.068352 & 0.037417 & -1.826761 & 0.0714 \\
\hline İMALAT & -0.042350 & 0.034415 & -1.230582 & 0.2220 \\
\hline ELEKTRIK, GAZ, SU & -0.372966 & 0.205667 & -1.813451 & 0.0734 \\
\hline $\begin{array}{c}\text { ULAŞTIRMA, HABERLEŞME, } \\
\text { DEPOLAMA }\end{array}$ & -0.060410 & 0.033445 & -1.806261 & 0.0745 \\
\hline $\mathrm{R}^{2}$ & 0.360453 & $\begin{array}{l}F \text { istatistiği P } \\
\text { değeri }\end{array}$ & 0.000003 & \\
\hline $\mathrm{F}$ istatistiği & 6.602253 & $\begin{array}{l}\text { Durbin Watson } \\
\text { İstatistiği }\end{array}$ & 1.860131 & \\
\hline
\end{tabular}

Tablo-7'den görüleceği üzere modelin anlamlılığını gösteren $\mathrm{F}$ istatistiğinin p değeri (0.000003) 0,05'ten küçüktür. Bu, modelin istatistiki olarak anlamlı olduğunu göstermektedir. $R^{2}$ değerinin 0,360453 olması ise; bağımIı değişkende meydana gelebilecek \%36'lık değişmenin, bu modelde yer alan bağımsız değişkenlerdeki değişimlerle açıklanabileceğini ortaya koymaktadır. Bu oranın yüksek olması modelin gücünü artırmaktadır. Durbin Watson istatistik değerinin 2'ye yakın olması $(1,86)$ da modelde otokorelasyon sorununun olmadığını göstermektedir.

Modelin istatistiki olarak anlamlı çıkması fakat bağımsız değişken katsayılarının anlamsız çıkması; sektörler dikkate alındığında sürdürülebilirlik performans göstergelerine ilişkin açıklanan bilgi düzeyinin özkaynak karlılığı üzerinde etkisinin olmadığını ifade etmektedir. Çünkü ÇEV'in özkaynak karlılığı üzerindeki etkisini gösteren katsayı, sektörler modele dahil edildikten sonra istatistiki olarak anlamsız çıkmıştır. Diğer bir ifadeyle ÇEV'in etkisi sektörler dikkate alındıktan sonra değişmektedir. Böylelikle bağımsız değişkenlerin hepsinin etkisi istatistiki olarak anlamsız olmuştur. Dolayısıyla sektörler arasında şirketlerin ortalama sürdürülebilirlik performans göstergelerine ilişkin açıklama düzeyleri arasındaki farklılıklar önemli hale gelmektedir. Bu sonuçlara göre; H2a hipotezi RED edilir.

\subsection{Sürdürülebilirlik Performans Göstergelerine İlişkin Açılklanan Bilgi Düzeyinin PD/DD Oranı Üzerindeki Etkisine Yönelik Bulgular}

Sürdürülebilirlik performans göstergelerine ilişkin (EKO, ÇEV ve SOS) açıklanan bilgi düzeyinin PD/DD oranı üzerine etkisi Hausman testi sonuçlarına 
göre tesadüfi etkiler panel veri analizi yöntemiyle incelenmiştir. Analiz sonuçları Tablo-8'de yer almaktadır.

Tablo-8: Sürdürülebilirlik Skorlarının PD/DD Oranı Üzerindeki Etkisi

\begin{tabular}{|c|c|c|c|c|}
\hline \multicolumn{2}{|l|}{ Bağımlı değişken: PD/DD oranı } & \multicolumn{2}{|l|}{} & \\
\hline Bağımsız değişkenler & Katsayılar & Standart hatalar & t istatistikleri & p(olasılık) \\
\hline C & 1514614 & 0.420909 & 3.598434 & 0.0005 \\
\hline EKO & -0.033209 & 0.033344 & -0.995959 & 0.3221 \\
\hline ÇEV & 0.007335 & 0.009418 & 0.778872 & 0.4382 \\
\hline SOS & 0.011820 & 0.004730 & 2.499050 & 0.0144 \\
\hline$R^{2}$ & 0.063241 & F istatistiği P değeri & 0.129903 & \\
\hline F istatistiği & 1.935286 & $\begin{array}{c}\text { Durbin Watson } \\
\text { İstatistiği }\end{array}$ & 1.147462 & \\
\hline
\end{tabular}

Tablo-8'den görüleceği üzere modelin anlamlılı̆ı̆ı gösteren $\mathrm{F}$ istatistiğinin $\mathrm{p}$ değeri $(0,129903) 0,05$ 'ten büyüktür. $\mathrm{Bu}$, modelin istatistiki olarak anlamlı olmadığını göstermektedir. $R^{2}$ değerinin de 0,06 gibi düşük çıkması; bağımsız değişkenlerin, bağımlı değişken olan PD/DD oranı üzerinde meydana gelebilecek değişimleri açıklamada önemli bir etkiye sahip olmadığını göstermektedir. Diğer bir ifadeyle PD/DD oranında meydana gelecek değişimler, modelin bağımsız değişkenleri olan EKO, ÇEV ve SOS tarafindan açıklanamamaktadır. Bu sonuçlara göre; H3 hipotezi RED edilir (Modelin p değeri 0,129903>0,05).

Sektör: Sektörlerin daha önce oluşturulmuş olan panel veri modeline (model 3) kontrol değişkeni olarak dahil edilmesi suretiyle gerçekleştirilen panel veri analizine yönelik sonuçlar Tablo-9'da gösterilmiştir:

Tablo-9: Sektörlerin PD/DD Oranı Üzerindeki Etkilerinin Analizi

\begin{tabular}{|c|c|c|c|c|}
\hline Bağımlı değişken: PD/DD & & & & \\
\hline Bağımsız değişkenler & Katsayılar & Standart hatalar & t istatistikleri & p(olasılık) \\
\hline C & 0.617084 & 1.276243 & 0.483516 & 0.6300 \\
\hline EKO & -0.031789 & 0.033147 & -0.959032 & 0.3404 \\
\hline ÇEV & 0.006609 & 0.009693 & 0.681821 & 0.4973 \\
\hline SOS & 0.012240 & 0.004734 & 2.585358 & 0.0115 \\
\hline MALi & -0.229219 & 1.140781 & -0.200932 & 0.8412 \\
\hline IMALAT & 1.596056 & 0.847264 & 1.883777 & 0.0631 \\
\hline ELEKTRIK, GAZ, SU & 0.450584 & 1.416871 & 0.318013 & 0.7513 \\
\hline ULAŞTIRMA, & 0.740791 & 1.239298 & 0.597751 & 0.5517 \\
\hline HABERLEŞME, DEPOLAMA & 0.156252 & F istatistiği P değeri & 0.045344 & \\
\hline R & 2.169347 & $\begin{array}{c}\text { Durbin Watson } \\
\text { isstatistiği }\end{array}$ & 1.316221 & \\
\hline F istatistiği & & & & \\
\hline
\end{tabular}


Tablo-9'dan görüleceği üzere modelin anlamlılığını gösteren $\mathrm{F}$ istatistiğinin p değeri $(0,045344)$ 0,05'ten küçüktür. Bu, modelin istatistiki olarak anlamlı olduğunu göstermektedir. $R^{2}$ değerinin 0,156252 olması ise; bağımlı değişkende meydana gelebilecek yaklaşık \%16'lık değişmenin, bu modelde yer alan bağımsız değişkenlerdeki değişimlerle açıklanabileceğini ortaya koymaktadır. Bu oranın yüksek olması modelin gücünü artırmaktadır.

Modelin istatistiki olarak anlamlı çıkması; sektörler dikkate alındığında sürdürülebilirlik performans göstergelerine ilişkin açıklanan bilgi düzeyinin PD/DD oranı üzerinde etkisinin olduğunu ifade etmektedir. Sektörler modele dahil edildiğinde SOS'un PD/DD oranı üzerindeki etkisi anlamlı hale gelmiştir. Dolayısıyla sektörlerin SOS'un PD/DD oranı ile ilişkisinde etkili olduğu söylenebilir. Bu sonuçlara göre; H3a hipotezi KABUL edilir (Modelin $p$ değeri $0,045344<0,05)$.

\subsection{Sürdürülebilirlik Performans Göstergelerine İlişkin Açıklanan Bilgi Düzeyinin F/K Oranı Üzerindeki Etkisine Yönelik Bulgular}

Sürdürülebilirlik performans göstergelerine ilişkin (EKO, ÇEV ve SOS) açıklanan bilgi düzeyinin $\mathrm{F} / \mathrm{K}$ oranı üzerine etkisi Hausman testi sonuçlarına göre tesadüfi etkiler panel veri analizi yöntemiyle incelenmiştir. Analiz sonuçları Tablo-10'da yer almaktadır.

Tablo-10: Sürdürülebilirlik Skorlarının F/K Oranı Üzerindeki Etkisi

\begin{tabular}{|c|c|c|c|c|}
\hline \multicolumn{2}{|c|}{ Bağımlı değişken: F/K oranı } & & \\
\hline Bağımsız değişkenler & Katsayılar & $\begin{array}{c}\text { Standart } \\
\text { hatalar }\end{array}$ & t istatistikleri & p(olasılık) \\
\hline C & 1691443 & 6.169686 & 2.741537 & 0.0076 \\
\hline EKO & -0.165195 & 0.262894 & -0.628370 & 0.5316 \\
\hline ÇEV & -0.056996 & 0.070996 & -0.802804 & 0.4245 \\
\hline SOS & -0.052252 & 0.111093 & -0.470342 & 0.6394 \\
\hline$R^{2}$ & 0.023754 & $\begin{array}{c}\text { F istatistiği P } \\
\text { değeri }\end{array}$ & 0.596164 & \\
\hline F istatistiği & 0.632635 & $\begin{array}{c}\text { Durbin } \\
\text { Watson } \\
\text { ístatistiği }\end{array}$ & 1.140010 & \\
\hline
\end{tabular}

Tablo-10'dan görüleceği üzere modelin anlamlılığını gösteren F istatistiğinin p değeri $(0,596164) 0,05^{\prime}$ ten büyüktür. $\mathrm{Bu}$, modelin istatistiki olarak anlamlı olmadığını göstermektedir. $\mathrm{R}^{2}$ değerinin de 0,02 gibi düşük çıkması; bağımsız değişkenlerin, bağımlı değişken olan F/K oranı üzerinde meydana gelebilecek değişimleri açıklamada önemli bir etkiye sahip olmadığını göstermektedir. Diğer bir ifadeyle F/K oranında meydana gelecek değişimler, modelin bağımsız değişkenleri olan EKO, ÇEV ve SOS tarafindan açıklanamamaktadır. Ayrıca modelin bağımsız değişkenleri olan EKO, ÇEV ve SOS'a 
ait $p$ değerleri de 0,05 'ten büyük, yani istatistiki olarak anlamsızdır. Bu sonuçlara göre; H4 hipotezi RED edilir (Modelin p değeri 0,596164>0,05).

Sektör: Sektörlerin daha önce oluşturulmuş olan panel veri modeline (model 4) kontrol değişkeni olarak dahil edilmesi suretiyle gerçekleştirilen panel veri analizine yönelik sonuçlar Tablo-11'de gösterilmiştir:

Tablo-11: Sektörlerin F/K Oranı Üzerindeki Etkilerinin Analizi

\begin{tabular}{|c|c|c|c|c|}
\hline Bağımlı değişken: $F / K$ & & & & \\
\hline Bağımsız değişkenler & Katsayılar & Standart hatalar & $\mathrm{t}$ istatistikleri & $\mathrm{p}$ (olasılık) \\
\hline C & 1.085782 & 1.016627 & 1.068023 & 0.2890 \\
\hline EKO & -0.118475 & 0.314409 & -0.376818 & 0.7074 \\
\hline ÇEV & -0.044793 & 0.082672 & -0.541813 & 0.5896 \\
\hline SOS & -0.046873 & 0.126075 & -0.371788 & 0.7111 \\
\hline MALi & 1.302841 & 3.666586 & 0.355328 & 0.7234 \\
\hline IMALAT & 8.680257 & 3.221969 & 2.694085 & 0.0087 \\
\hline ELEKTRIK, GAZ, SU & -3.848544 & 8.753934 & -0.439636 & 0.6615 \\
\hline $\begin{array}{c}\text { ULAŞTIRMA, HABERLEŞME, } \\
\text { DEPOLAMA }\end{array}$ & 4.926613 & 7.637757 & 0.645034 & 0.5209 \\
\hline $\mathrm{R}^{2}$ & 0.073505 & $\begin{array}{c}\text { F istatistiği P } \\
\text { değeri }\end{array}$ & 0.558854 & \\
\hline $\mathrm{F}$ istatistiği & 0.838703 & $\begin{array}{l}\text { Durbin Watson } \\
\text { İstatistiği }\end{array}$ & 1.213690 & \\
\hline
\end{tabular}

Tablo-11'den görüleceği üzere modelin anlamlılığını gösteren $\mathrm{F}$ istatistiğinin $p$ değeri $(0,558854) 0,05$ 'ten büyüktür. Bu durum, modelin istatistiki olarak anlamlı olmadığını göstermektedir. Diğer bir ifadeyle bağımsız değişkenlere ve kontrol değişkenlerine ait katsayılar anlamlı bir sonuç ifade etmemektedir. Ayrıca $R^{2}$ değerinin 0,073505 oldukça düşük çıkması, bağımsız değişkenlerin bağımlı değişken olan $\mathrm{F} / \mathrm{K}$ oranı üzerinde önemli bir etkiye sahip olmadığını göstermektedir.

Modelin istatistiki olarak anlamsız çıkması; sektörler dikkate alındığında sürdürülebilirlik performans göstergelerine ilişkin açıklanan bilgi düzeyinin $\mathrm{F} / \mathrm{K}$ oranı üzerinde etkisinin olmadığını ifade etmektedir. Sektörler modele dahil edilmediğinde de EKO, ÇEV ve SOS'un F/K oranı üzerindeki etkisi anlamsız olduğu için; sektörlerin EKO, ÇEV ve SOS'un F/K oranı ile ilişkisinde etkili olmadığı diğer bir ifadeyle sektörlere bağlı olarak F/K oranına olan etkinin değişmediği söylenebilir. Bu sonuçlara göre; $\mathrm{H} 4 \mathrm{a}$ hipotezi RED edilir (Modelin p değeri 0,558854>0,05).

Panel veri analizi sonuçları genel olarak değerlendirildiğinde; sürdürülebilirlik performans göstergelerine ilişkin açıklanan bilgi düzeyini temsilen modele dahil edilen ÇEV ve SOS bağımsız değişkenlerinin muhasebe temelli ölçüler olan aktif karlılığı ve özkaynak karlılığı oranları üzerindeki et- 
kisinin istatistiki olarak anlamlı olduğu sonucuna ulaşılmıştır. ÇEV, hem aktif karlılığı hem de özkaynak karlılığı; SOS ise sadece aktif karlılığı üzerinde pozitif bir etkiye sahiptir. Diğer bir ifadeyle çevresel ve sosyal performans göstergelerine yönelik açıklanan bilgi düzeyinde meydana gelebilecek her birimlik artış aktif karlılığı üzerinde; çevresel performans göstergelerine yönelik açıklanan bilgi düzeyinde meydana gelebilecek her birimlik artış ise özkaynak karlılığı üzerinde olumlu yönde etki gösterecektir. Bununla birlikte EKO, ÇEV ve SOS bağımsız değişkenlerinin piyasa temelli ölçüler olan PD/DD ve F/K oranları üzerinde istatistiki olarak anlamlı bir etkiye sahip olmadığı sonucuna varılmıştır. Piyasa temelli oranlar; piyasada var olan birçok faktör ve beklentiden etkilenerek şekillenebildiği için elde edilen sonuçlar, çalışmanın bağımsız değişkenleri olan EKO, ÇEV ve SOS'un PD/DD ve F/K oranı üzerinde anlamlı bir etkiye sahip olmadığını göstermiş olabilir.

Sektörler dikkate alındığında; sektörlerin sürdürülebilirlik performans göstergelerine ilişkin açıklanan bilgi düzeyi (ÇEV ve SOS) ile aktif karlılığı, özkaynak karlılığı ve PD/DD oranı ilişkisi üzerinde etkili olduğu ve F/K oranı ile ilişkisinde etkili olmadığı sonucu ortaya çıkmıştır. Bu etki muhasebe temelli ölçüler olan aktif ve özkaynak karlıığında daha belirginken, piyasa temelli ölçülerden PD/DD oranı üzerinde ise daha az belirgindir. Bunun nedenleri arasında; sektöre özgü dinamiklerin, şirketin içsel verimliliğine ilişkin muhasebe temelli ölçüler üzerinde daha belirleyici olmasının yer aldığı söylenebilir.

\section{SONUÇ}

İşletmelerin son yıllarda sürdürülebilirlik konusuna verdikleri önem artmış ve bu durum sürdürülebilirlik raporlarıyla kendini göstermiştir. Bununla birlikte işletmelerin sürdürülebilirlik konusundaki faaliyetlerinin finansal açıdan yansımaları ilgi çeken konuların başında gelmektedir. Türkiye'de sürdürülebilirlik raporu yayınlayan şirket sayısının azlığı ve rapor yayınlama geçmişinin çok eskilere dayanmamasına bağlı olarak sürdürülebilirlik ve finansal performans arasındaki ilişkinin incelenmesine yönelik az sayıda çalışma bulunmaktadır.

Bu çalışmanın amacı; sürdürülebilirlik performans göstergelerine ilişkin açıklanan bilgi düzeyinin finansal performans üzerine etkilerini belirlemektir. Bu amaçla 2008-2014 yılları arasında GRI'ya göre sürdürülebilirlik raporu yayınlayan ve hisseleri BisT'te işlem gören şirketler incelenmiştir. Panel veri analizinin kullanıldığı çalışmanın sonuçlarına göre; ekonomik performans göstergelerine ilişkin açıklanan bilgi düzeyinin finansal performans göstergesi olarak seçilen dört gösterge üzerinde de istatistiki olarak anlamlı bir etkiye sahip olmadığı görülmüştür. Bununla birlikte çevresel 
performans göstergelerine ilişkin açıklanan bilgi düzeyinin, muhasebe temelli ölçüler olan aktif karlılığı ve özkaynak karlılığı üzerinde istatistiki olarak anlamlı pozitif bir etkiye sahip olduğu görülmüştür. Bu sonuç; şirketlerin sürdürülebilirlik raporlarında çevresel konularda açıkladıkları bilginin artmasının, aktif karlılı̆ıı ve özkaynak karııı̆ı̆ı olumlu bir şekilde etkilediğini göstermektedir. Ayrıca çevresel performans göstergelerine ilişkin açıklanan bilgi düzeyinin, piyasa temelli göstergeler olan $\mathrm{PD} / \mathrm{DD}$ ve $\mathrm{F} / \mathrm{K}$ oranı üzerinde istatistiki olarak anlamlı bir etkiye sahip olmadığı sonucu görülmüştür. Sosyal performans göstergelerine ilişkin açıklanan bilgi düzeyinin ise sadece aktif karlıı̆ı üzerinde istatistiki olarak anlamlı pozitif bir etkiye sahip olduğu; özkaynak karlılığı, PD/DD ve F/K oranı üzerinde ise anlamlı bir etkiye sahip olmadığı sonucuna ulaşılmıştr. Diğer bir ifadeyle, şirketlerin sürdürülebilirlik raporlarında sosyal performans göstergelerine ilişkin açıkladıkları bilgiyi artırmalarının aktif karııı̆ı̆ını olumlu olarak etkileyeceği söylenebilir. Burada dikkat çeken nokta; çevresel ve sosyal performans göstergelerine ilişkin açıklanan bilgi düzeyinin muhasebe temelli göstergeler üzerinde anlamlı bir etkiye sahip olduğudur. Piyasa temelli göstergeler üzerinde ise anlamlı bir etki görülmemiştir. Bu durum; $P D / D D$ ve $F / K$ oranı göstergeleri üzerinde hisse senedi piyasasına özgü daha farkı faktörlerin etkili olduğu şeklinde değerlendirilebilir.

Çalışmanın sonuçlarına göre sektörlerin; sürdürülebilirlik performans göstergelerine ilişkin açıklanan bilgi düzeyinin aktif karlııı̆ı, özkaynak karlılığı ve $P D / D D$ oranı ile ilişkisinde etkili olduğu söylenebilir.

Özetle çalışmada ulaşılan sonuçlar; şirketler açısından sürdürülebilirlik raporu yayınlamanın önemini ortaya koymaktadır. Ayrıca sektörel farkıııkların, gerek sürdürülebilirlik raporlarında açıklanan bilgi düzeyinde gerekse sürdürülebilirlik performansı ve finansal performans arasındaki ilişkide önemli bir etken olduğu görülmüştür. Türkiye'de GRI'ya göre sürdürülebilirlik raporu yayınlayan şirket sayısının her geçen yıl artş göstermesine bağlı olarak, ileride daha geniş bir zaman aralığıı kapsayan analiz dönemi seçilerek çalışmalar yapılabilir. Bu doğrultuda ileride yapılacak çalışmalarda sürdürülebilirlik raporu yayınlamanın daha uzun vadeli etkileri incelenebilir. 
Alexander, G. J., Buchholz, R. A. (1978). Corporate social responsibility and stock market performance. Academy of Management Journal, 21(3), 479486.

Ameer, R., Othman, R. (2012). Sustainability practices and corporate financial performance: A study based on the top global corporations. Journal Business Ethics, 108, 61-79.

Arsoy, A.P., Arabacı, Ö., Çiftçioğlu A. (2012). Corporote social responsibility and financial performance relationship: The case of Turkey. Muhasabe ve Finansman Dergisi, 53(1), 159-176.

Aupperle, K. E., Carroll, A. B., Hatfield, J. D. (1985). An empirical examination of the relationship between corporate social responsibility and profitability. Academy of Management Journal, 28(2), 446-463.

Backström, S.L., Karlsson, J. (2015). Corporate sustainability and financial performance-the influence of board diversity in a Swedish context. Master Tezi. İsveç: Uppsala Üniversitesi.

Baltagi, B.H. (2005). Econometric analysis of panel data.(3rd edition). Ingiltere: John Wiley \& Sons.

Belu, C. (2009). Ranking Corporations Based on Sustainable and Socially Responsible Practices. A Data Envelopment Analysis (DEA) Approach. Sustainable Development, 17, 257-268.

BIST, (2014). Sürdürülebilirlikle Ilgili Özet Bilgiler. Erişim tarihi:10.06.2014. http://borsaistanbul.com/datum/surdurulebilirlik/SURDURULEBILIRLIK_ OZET_BILGILER.pdf

Brutland, G.H. (1987). Our common future, report of the world commission on environment and development. Erişim tarihi: 25.08.2013. http:// www.un-documents.net/our-common-future.pdf

Choi, J., Wang, H. (2009). Stakeholder relations and the persistence of corporate financial performance. Strategic Management Journal, 30, 895907.

Cornell, B., Shapiro, A.C. (1987). Corporate stakeholders and corporate finance. Financial Management, Spring 1987, 5-14.

Erdemi, D. B. (2015). AR-GE yatırımları finansal performans ilişkisi: Bir panel veri analizi. Yüksek Lisans Tezi. İstanbul: Yıldız Teknik Üniversitesi.

Friedman, M. (1970). The social responsibility of business is to increase its profits", New York Times Magazine, Eylül 13, 122-126. 
Greene, W.H. (2002). Econometric analysis. (5th edition). ABD: Prentice Hall.

GRI, (2016). About GRI. Erişim tarihi: 13.02.2016. https://www.globalreporting.org/information/about-gri/Pages/default.aspx.

Gujarati, D.N., Porter, D.C. (2014). Temel ekonometri. (Çev. Ü. Şenesen ve G. Günlük Şenesen). İstanbul: Literatür Yayınları.

Kutlar, A. (2005). Uygulamalı Ekonometri. (2.baskı). Ankara: Nobel Yayın Dağıtım.

Lee, D.D., Faff, R.W., Smith, K.L. (2009). Revisiting the vexing question: Does superior corporate social performance lead to improved finacial performance. Australian Journal of Management, 34(1), 21-49.

Lopez, M.V., Garcia, A., Rodriguez, L. (2007). Sustainable development and corporate performance: A study based on the Dow Jones Sustainability Index. Journal of Business Ethics, 75, 285-300.

Lozano, R., Huisingh, D. (2011). Inter-linking Issues and Dimensions in Sustainability Reporting. Journal of Cleaner Production, 19 (2011), 99-107.

McWilliams, A., Siegel, D. (2001). Corporate social responsibility: A theory of the firm perspective. Academy of Management Review, 26(1), 117-127.

Morhardt, J.E., Baird, S., Freeman, K. (2002). Scoring corporate environmental and sustainability reports using GRI 2000, ISO 14031 and other criteria. Corporate Social Responsibility and Environmentol Management, 9, 215-233.

Moskowitz, M. R. (1972). Choosing socially responsible stocks. Business and Society, 1, 71-75.

Nyit Chiong, P.T.(2010). An Examination of Corporate Sustainability Disclosure Level and Its Impact on Financial Performance. Doktora Tezi. Malezya: Multimedia University.

Onay, A. (2015). Sürdürülebilir Kalkınma, Kurumsal Sürdürülebilirlik ve Sürdürülebilirlik Raporlaması. Elektronik Mesleki Gelişim ve Araştırma Dergisi, Aralık 2015, 3(Özel Sayı), 104-118.

Önce, S., Onay, A., Yeşilçelebi, G. (2015) Kurumsal Sürdürülebilirlik Raporlaması ve Türkiye'deki Durum. Journal of Economics Finance and Accounting, 2 (2), 230-252.

Özçelik, F., Öztürk, B.A., Gürsakal, S. (2014). Investigating the relationship between corporate social responsibility and financial performance in Turkey. Atatürk Üniversitesi IiBF Dergisi, 28(3), 189-202. 
Pazarlıoğlu, M. V., Gürler, Ö. K. (2007). Telekomünikasyon yatırımları ve ekonomik büyüme: Panel veri yaklaşımı. Finans Politik \& Ekonomik Yorumlar, 44(508), 35-43.

Peters, R., Mullen, M.R. (2007). Some evidence of the cumulative effects of corporate social responsibility on financial performance. The Journal of Global Business Issues, 3(1), 1-15.

Preston, L.E., Q'Bannon D.P. (1997). The Corporate Social-Financial Performance Relationship: A Typology Analysis. Business and Society, 36(4), 419-429.

Salzman, O., Somers, A.I., Steger, U. (2005). The business case for corporate sustainability: Literatür review and research options. Europen Management Journal, 23(1), 27-36.

Tatoğlu, F.Y. (2013). Illeri panel veri analizi stata uygulamalı (2.baskı). İstanbul: Beta Basım Yayım Dağıtım.

Tatoğlu, F.Y. (2016). Panel veri ekonometrisi (3.baskı). İstanbul: Beta Basım Yayım Dağıtım.

Ullman, A. (1985). Data in search of a theory: A critical examination of the relationships among social performance, social disclosure and economic performance of U.S. firms. Academy of Management Review, 10(3), 540557.

Vance, S. C. (1975). Are socially responsible corporations good investment risks?. Management Review, 64, 18-24.

Waddock, S.A., Graves, S.B.(1997). The Corporate Social Performance-Financial Performance Link. Stratejic Management Journal, 18(4), 303-319.

Welter, K.A. (2011). A Study of Publicly-Held U.S. Corporations on the Effects of Sustainability Measures on Financial Performance, Utilizing a Modified Regression Discontinuity Model. Doktora Tezi. Lawrence Technological University.

Yıldırtan, D.Ç. (2010). E-Views Uygulamalı Temel Ekonometri Makro Ekonomik Verilerle. (1.Baskı). İstanbul: Türkmen Kitabevi.

Yılmaz, I. (2011). Corporote Social Responsibility Diclosures As An Indicator of Social Performance and Its Relation with Financial Performance. Doktora Tezi. İstanbul: Marmara Üniversitesi. 